\title{
Determinants of Export Growth Rate: The Case of Madagascar
}

\author{
Seraphin Tovonjatovo ${ }^{1} \&$ Yinguo Dong ${ }^{2}$ \\ ${ }^{1}$ School of Economics, Shanghai University, Shanghai, China \\ ${ }^{2}$ School of Business, East China University of Science and Technology, Shanghai, China \\ Correspondence: Yinguo Dong, School of Business, East China University of Science and Technology, Shanghai, \\ China. E-mail: dongyinguo2005@163.com
}

Received: May 18, 2015

Accepted: July 2, 2015

Online Published: August 25, 2015

doi:10.5539/ijef.v7n9p105

URL: http://dx.doi.org/10.5539/ijef.v7n9p105

\begin{abstract}
This paper uses econometric analysis to explore the determinants of export growth rate in Madagascar over the period 1985-2013. Based on the model, variables of export price, Foreign Direct Investment (FDI), world Income, terms of trade, real exchange rate and farm gate price are employed. The results show that export growth rate, export price, FDI, world income, terms of trade, real exchange rate and farm gate price are co integrated. The estimated long run (short run) elasticity of export growth rate with terms of trade show significantly a positive impact on export growth rate whereas farm gate price negative effect. However, in term of the real exchange rate, in short run, it stimulates export growth as an incentive in form of depreciation of the currency but in long run the positive elasticity expressing an appreciation of the currency affect export growth rate negatively. The FDI and world income a weak positive influence on the export growth rate. The effect of export price level on export growth rate is not verified implying that the price does not explain export growth rate in Madagascar.
\end{abstract}

Keywords: export growth, cointegration, error correction model, and madagascar

\section{Introduction}

As suppliers of raw materials to western economies, since the Independence Day, many of the Africans countries' economies have continued to produce goods for export. As evidenced by the rising of cash crops such as Vanilla, coffee, which Madagascar is a good suppliers around the world situated between Indonesia and Brazil. Madagascar is an agricultural country where agriculture is one of the key pillars of the economy. The country has a great asset on the production and export of tropical products. Agriculture, forestry, and fisheries account for a substantial part of GDP and exports. Madagascar produces $40 \%$ of the world's Vanilla and major exporter of bananas, coffee, cotton, palm oil, pineapples, litchis and tropical wood products. Almost 70\% of the Malagasy people are engaged in some form of agricultural activity. Consequently, the economy is highly sensitive to fluctuations in international prices for agricultural products and to weather conditions. Despite attempts by the government to diversify the economy, Madagascar is still largely dependent on agriculture and related activities. The United States, the European Union and common market for Eastern and Southern Africa States are Madagascar major trading partner and this has been ongoing since the Independence Day. For example in 2008, U.S. goods imports from Madagascar totaled \$1.1 billion, an 81.9\% increase (\$492 million) from 2007.Thereby the governments have implemented many policies such us new political Industrial (NPI) and streamline the exportation to enhance the export sector. Structural Adjustment Programmes (SAPs), supported by IMF and the World Bank, focused on export development regardless of their sectoral features, which reinforced the traditional exports of Madagascar (Vanilla, coffee, wood products and fresh fruits). The government also introduced then an export support scheme based on export subsidies and import tax rebate on inputs used in export activities. Along with these efforts an industrial development plan was designed with the support of UNIDO (Ministry of trade 1988). The plan analyzed the potentially exporting products, identified the required production chain developments, and devised options for different industrial strategies. Due to financial problems, the plan was not implemented. But, the thrust of the plan paved the way for a consistent industrial policy based on an increase in industrial value added and exports, the strengthening of the linkages in industrial activities, between the industrial sector, agricultural production and the service sector.

Indeed, over the period 1985 to 2013, export has experienced annual variation rang and the export growth rate, 
with its determinants, is among the results of this. So after more than two decades of reform and given the evolution of some macroeconomic indicators in Madagascar, the question is arise to understand what is the determinant of export growth rate in Madagascar.

The export growth hypothesis is one of the most debated topics in the recent past with little consensus. The debate, which dates back to the classical and neoclassical economic theories, centers on the role of exports as one of the main determinants of economic growth. Adam Smith, James Mill and David Ricardo on whose shoulders the argument rests, posited that participation in international trade could be a strong positive force in the economic development process of nations and economic gains from specialization. Some related reasons analyzed to support this argument are that promoting exports encourages production of goods, which provides the economy with foreign exchange that may further enable importation of capital inputs that cannot be produced domestically.

Previous studies on the determinants of export performance in developing countries show that Foreign Direct Investment (FDI) has a significant positive impact on export Structure. Van Dijk (2002) conducts a similar study on Indonesia and finds out that foreign Direct Investment is very significant by explaining its export performance. According to Abdulai and Jaquet (2002), export growth may lead to increased scope of economies of scale. Economies of scale result from enlargement of market size due to efficient allocation of resources and competitiveness of exporting firms.

Morrissey and Mold (2006) analyze about export performance and find that the problem of export performance in Africa is associated with trading a kind of primary commodities with low value-added and low price. Such products are very elastic to demand on world market and thus lead a serious detrimental for the African countries in term of enhancing efficiency. In South Africa, Edwards and Golub (2004) find that foreign prices have a strong impact on manufacturing sector's export performance. They use time series data and got a significant positive coefficient of foreign prices.

An UNCTAD study finds that internal transport plays an important role in determinant of export performance. It has a positive significance among the better performing exporters while a negative impact on export performance allied from internal costs generated by the weakest performers. Most of the Least Developed African countries are characterized by poor transport infrastructure, and in a long period show to be poor export performers. This appears to indicate that African countries could do much to raise their supply capacity by investing on transport infrastructure. Export growth in Africa continues to be stunted by various obstacles. One of the most important constraints is the political instability. Three types of political instability are recognized: Elite, Communal and Mass instability. The instability involves the forceful removal, from office, of the leaders of a country's government. McGowan and Johnson (1984) affirm that instability is attempted coup and plots to displace the government. They conclude that the variable political instability affect negatively export expansion.

Thus, this study attempts to settle about the problems stated above through the analysis focuses on the estimation of the export growth rate in Madagascar, using the Ordinary Least Square (OLS) estimation technique over the years 1985 to 2013 by understanding the theories concerning the co-integration, the positive and significance between the used variables.

The paper is organized as follow: the methodology description is presented in section 2, empirical results come next and section 4 is the discussion.

\section{Methodology}

\subsection{Theoretical Framework of the Model}

The study is conducted by using data obtained from the National Institute of Statistics of Madagascar, Ministry of commerce and World Bank tables. To analyze the export growth rate we use E-views and co-integration method on time series data covering the period 1985-2013. The multiple regression models will be used to determine the factors affecting the Export Growth Rate. The Export price level, Foreign Direct Investment, World Income, Terms of Trade, Real Exchange Rate, political instability and Farm gate price will be the explanatory variables of Export Growth Rate in Madagascar. The export growth rate also will be specified in a $\log$-linear form. Therefore the Export Growth Rate equation can be expressed as follow:

$$
\begin{aligned}
& \quad E G R_{t}=\beta_{0}+\beta_{1} \operatorname{LnEXP}_{t}+\beta_{2} \operatorname{LnFDI}_{t}+\beta_{3} \operatorname{LnWY}_{t}+\beta_{3} \operatorname{LnTOT}_{t}+\beta_{4} \operatorname{LnRER_{t}}+\beta_{5} \operatorname{LnINST}_{t}+\beta_{6} \operatorname{LnFGP}_{t}+\varepsilon_{t} \\
& \text { Where: }
\end{aligned}
$$

$E G R=$ Export Growth Rate, EXP=Export Price Level, FDI=Foreign Direct Investment, WY=World GDP in US\$ is the proxy for world income, TOT=Terms of Trade, RER=Real Exchange Rate, INST=Indicator of elite 
political instability for the period 1999 to 2013, FGP=Farm gate price, $\boldsymbol{\varepsilon}=$ Term of error, $\boldsymbol{\beta}_{\boldsymbol{0}}=$ Constant

Where:

$$
E X P>0 ; F D I>0 ; W Y>0 ; T O T>0 ; R E R<0 ; I N S T<0 ; F G P>0
$$

\subsection{Hypothesis to Be Tested}

This study is testing the hypothesis zero influence of independent variables to dependent variable. It attempt to find out whether the independent variables have significant impact on dependent variable or not, and if $\beta_{\mathrm{j}}$ is significantly equal to zero or not. This hypothesis can be written as follow:

$\mathrm{H}_{0}: \beta_{\mathrm{j}}=0$

$\mathrm{H}_{\mathrm{i}}: \beta_{\mathrm{j}} \neq 0$

\subsection{Data Type and Source}

The research is bolstered by substantial literature reviews where data was analyzed and synthesized by using a content analysis technique or analytical technique. The reports from the national institute of statistics, newspapers, pamphlets and annual reports from Ministry of commerce and World Bank tables are part of this work. The books, journals and research articles helped in simplifying issues of export growth rate in Madagascar; a theoretical approach based on document exploitation supported by most recent data and case study have been used to address this question in four chapters.

\subsection{Time Series Properties of the Economic Variables}

Non-stationary time series data has often been regarded as a problem in empirical analysis. Working with non-stationary variables leads to spurious regression results from which further inference is meaningless when these variables are estimates in their levels. In order to overcome this problem there is a need for testing the stationary of the microeconomic variables. The unit roots are performed in order to determine time series characteristics. This test is important as it shows that the number of times the variable has to be differenced to reach the stationary value. In general, the stationary variables are called I (0) series and those, which are to be differenced in order to achieve a stationary value is, called I (1) series. Classical econometric theory assumes that observed data come from a stationary process, where means and variances are constant over time implying that both are not a function of time. For a given set of non-stationary variables, their means and variances are functions of time. Testing for stationary provides an analysis for the summary of description statistics.

\subsection{Estimation Technique and Regression Analysis of the Model}

The model has been estimated by using Ordinary Least Square (OLS) estimation technique. The choice of this technique is due to its simplicity, convenience and the fact that it has been successfully used by others studies and gives out meaningful results. This technique provide unbiased estimated of the long run model and valid t-statistics

\subsection{Unit Root Test}

Modern time series analysis has established that regression with non-stationary variables may lead to nonsense regression results (Hendry \& juselius, 2000). These regression results might indicate the existence of extremely high correlation between variables; therefore there is no ready causal explanation. The recent development of unit root in econometrics has facilitated the problem in a more constructive way. In order to avoid specious regression result, stationary value of these series is important. The unit root test is a current approach used to conduct stationary tests. This study uses the ADF unit root test for the presence of unit root.

Table 1. Unit root test results: At first difference

\begin{tabular}{lcc}
\hline Variables & ADF Test Statistic & Order of Integration \\
\hline DlnEGR & -3.176 & $\mathrm{I}(1)^{*}$ \\
DlnEXP & -4.749 & $\mathrm{I}(1)^{*}$ \\
DlnFDI & -3.747 & $\mathrm{I}(1)^{*}$ \\
DlnWY & -4.389 & $\mathrm{I}(1)^{*}$ \\
DlnTOT & -3.318 & $\mathrm{I}(1)^{*}$ \\
DlnFGP & -3.957 & $\mathrm{I}(1)^{*}$ \\
\hline
\end{tabular}

At first differences, the Mackinnon critical value at $1 \%, 5 \%$ and $10 \%$ are respectively $-2.6603,-1.9552$ and 
-1.6228. However the ADF Test Statistic is less than the Mackinnon critical values, so the variables are not stationary at the different level significance. Therefore we reject the null hypothesis and this lead that all the typical results of the regression analysis can be valid.

\section{Result}

\subsection{Co Integration Johansen Test}

Since the variables are non stationary I (0) at level, then co integration Johansen (1995) is employed to test whether there is long run relationship between the dependent variable and the different independent variables.

Table 2. Co integration test result

\begin{tabular}{|c|c|c|c|c|}
\hline \multicolumn{5}{|c|}{ Included observations: 25} \\
\hline \multicolumn{5}{|c|}{ Test assumption: Quadratic deterministic trend in the data } \\
\hline \multicolumn{5}{|c|}{ 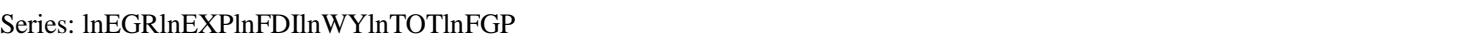 } \\
\hline \multicolumn{5}{|c|}{ Lags interval: No lags } \\
\hline & Likelihood & 5 percent & 1 percent & Hypothesized \\
\hline Eigenvalue & Ratio & Critical Value & Critical Value & No .cf CE (s) \\
\hline 0.848225 & 152.972 & 136.61 & 149.99 & None** \\
\hline 0.796796 & 105.838 & 104.94 & 114.36 & At most* \\
\hline 0.736826 & 66.00269 & 77.74 & 85.78 & At most ${ }^{2}$ \\
\hline 0.516428 & 32.62916 & 54.64 & 61.24 & At most ${ }^{3}$ \\
\hline 0.349404 & 14.46528 & 34.55 & 40.49 & At most ${ }^{4}$ \\
\hline 0.093096 & 3.718629 & 18.17 & 23.46 & At most ${ }^{5}$ \\
\hline 0.049747 & 1.275665 & 3.74 & 6.4 & At most ${ }^{6}$ \\
\hline
\end{tabular}

Note. $*(* *)$ denotes rejection of hypothesis at $5 \%(1 \%)$ significance level;

L.R test indicates 2 co-integration equations at $5 \%$ significance level.

The result from the co integration test to the Export growth is reported in Table 2.

The likelihood ratio has larger than the critical value for a significance level of 1 percent and 5 percent. The result indicates that Export growth, and its determinants, namely export price level, foreign direct investment, world income, term of trade, real exchange rate and farm gate price are co integrated; thus rejecting the null hypothesis of no cointegration between them. In other word, there is a long run relationship between the independent variables and export growth.

By the application of the Henry's (1995) general to-specific method, the estimated coefficients of the long run relationship between export growth and export price level, foreign direct investment, world income, term of trade, real exchange rate, farm gate price and dummy variable are presented as:

$$
E G R_{t}=-11.89-0.59 E X P_{t}+0.13 F D I_{t}+0.35 W Y_{t}+1.10 T O T_{t}+0.81 R E R_{t}-0.85 F G P_{t}
$$

Equation 2 shows that in long run world income, term of trade and foreign direct investment are positively related to export growth. The estimated elasticity of FDI, world income and term of trade are respectively 0.13 , 0.35 and 1.10. The implication of means that a 1percent increase in FDI, world income and term of trade will lead to 0.13 percent, 0.37 and 1.1percent increase in Export growth. As a priori expected, real exchange rate are not negatively correlated to export growth. This implies that in long run the country export growth will drop due to the appreciation of its currency.

The export price level and the farm gate price are not positively related with the export growth as they were hypothesized. This indicates that the export growth will also drop in long run due to the decline of world vanilla price and the farm gate price will continue to decrease by involving a dismay incentive of producer to produce. 


\section{Discussion}

4.1 Presentation of Empirical results

Table 3. Estimated ECM for the madagascar export growth

\begin{tabular}{ccccc}
\hline Explanatory variable & Estimated Coefficient & Std error & T-statistics & Probability \\
\hline DlnTOT & 0.07108 & 0.237863 & 3.328376 & 0.0058 \\
DlnRER & -0.01438 & 0.226327 & -3.024029 & 0.0065 \\
DlnFGP & -0.02528 & 0.131918 & -2.27072 & 0.0407 \\
\hline
\end{tabular}

$\mathrm{R}^{2}=0.52$, prob (F-statistic) $=0.000016, \mathrm{DW}=2.61$ and $\mathrm{n}=26$.

At the level of $5 \%, \mathrm{~F}_{0.05}(8,17)=2.55 ; \mathrm{F}$-statistic $>\mathrm{F}_{0.05}(8,17)$ so the model fitness is very good.

\subsection{Discussion of the Results}

$\mathrm{R}^{2}=0.52$ show that approximately $52 \%$ of the variation in export growth rate is explained by all the variables in the model. The model shows that the export price is insignificance, this could be explained by the result found by Musila (2004) where he analyzes the impact of the common market for eastern and southern Africa on Kenya export, and find that export growth is associated with volume exported and not high price for the product. The variable of world income is insignificant because large P-value. However the probability of observing at 10 percent one tail indicates that the estimated $t$-value $=1.71$ greater than the critical value. This means that at 10 percent one tail the world income is significant.

According to the OLS preferred model, if the buyers residing in Netherlands, partner's trade of Madagascar has their wealth increase by 1 percent, export earning would increase by 0.35 percent.

Inst representing by Political instability is not significant. This can be explained that the export crops, mainly Vanilla, coffee are growing in the east and southeastern part of the country which has been controlling by the republic force army and also the two harbor activities is concentrated in southeast region, which has facilities that include a fishing port and equipment for handling containers and San Toamasina city, a deepwater port that began operations in 1971.

The coefficient of Foreign Direct Investment (FDI) is positive and indicates that a one percent increase in investment in primary sector would lead a 0.011 percent of export growth in Madagascar. Compare the t-statistic $=1.89$ to the P-value at different level implies that FDI in Madagascar is insignificant on export growth, however only at 10 percent one tail the variable is significant, which is too weak. The justification of this result is that FDI in Madagascar is concentrated in Tertiary sector and Mining sector.

The model also shows that all P-values for $t$ tests on Term of trade (TOT), Real exchange rate (RER) and Farm gate price (FGP) are less than 5\% significance level, they are significant. The term of trade (TOT) and Real exchange rate (RER) are significant at 1percent level while Farm gate price is significant at 5 percent level two tailed.

The positive coefficient expected of the term of trade has been verified and the variable is very significant at 1 percent. The coefficient is also positive as expected in the model. Thus it indicates that an increase of 1percent of term of trade implies an increase of export growth by 0.07 percent. The role played by the variable is very important as it determines the favorable term of trade mentioned in the findings of Musinguzi, obwona and Stryker (2000) which, found out that terms of trade has a significant positive relationship with export growth rate but though an increase in terms of trade marginally increases export growth. Kasekende and Atingi-Ego have found out similar result, while studying the impact of trade liberalization key markets in Sub Saharan Africa; they discovered that export volumes are significantly correlated with term of trade.

The negative sign of the coefficient of Real exchange rate has shown the same result from what has been hypothesized. This implies that a rise of 1 percent of exchange rate leads to decline in export growth rate of -0.014 percent.

The possible explanation of this result is that an appreciation of real exchange rate (RER) implies a rise of the price of Madagascar's product in the international markets resulting into their decreased demand. The country export crops will be expensive compared to its competitors in the market. This will affect seriously detrimental the export growth, due to a decrease of the export volume.

The result obtained in this model is similar with other findings as Ghana and India by Fosu (1992) and Sharma 
(2001) respectively shown that real exchange rate has significant negative relationship with export growth. Sharma concluded that in domestic prices due to exchange rate depreciation makes exports cheaper in the international markets resulting in their increased demand. Cline (2004) also had a similar study using pooled data for over 100 developing countries for the period 1981-2001.He ran an Ordinary Least Squares regression and his results showed that real exchange rate has significant effect that is its depreciation. However Musinguzi and Obwona (2000) found that real exchange rate to have an insignificant effect on export growth rate.

The coefficient of farm gate price (FGP) was not positive as expected and statistically significant at 5 percent level. These indicate that farmers do not receive the real price of their effort due to the high taxation on the export crops, mainly Vanilla. And thereby the farmers are discouraged from fully participating in Vanilla production. A part from the high taxation on export of Vanilla, since 1960 Madagascar vanilla industry was regulated by a state institution which is PADR, the institution set an official export price, releasing exports negotiated by private exporters, selling a proportion of the crops and setting the pricing structure and farm gate price, which is the minimum price for the season no matter the price in world market.

\section{Acknowledgements}

First and foremost, I would like to thank my God, my Rock of ages, who has never left me alone in a foreign land and who has brought me this far. I would like next to express my gratitude to the department of international affaires of Shanghai University and especially to the school of economics for having accepted me to pursue a $\mathrm{PhD}$ Program at Shanghai University. Lastly, I would like to thank the National Natural Science Foundation of China (No.71373154), for the financial support.

\section{References}

Abdulai, A., \& Jaquet. P. (2002). Export and economic growth: Cointegration and Casualty. African Development Review, 14(11-17). http://dx.doi.org/10.1111/1467-8268.00043

African Economic outlook AFDB/OECD. (2008).

Alvarez, R. E. (2002). Determinants of firm export performance in a less developed country. Anderson Graduate School of Management, UCLA.

Amelia, U., \& Paulino, S. (2000). Trade liberalisation and export performance in selected developing countries. Studies in Economics, 12.

Bahman, O., \& Ltaifa, N. (1992). Effect of Exchange Rate risk on exports: Cross country analysis. World Development.

Balassa, B. (1978). Export and economic growth: Further evidence. Journal of Development Economics, June 1978, 181-189. http://dx.doi.org/10.1016/0304-3878(78)90006-8

Chakroun, M. (2002). Les déterminants de la compétitivité international du secteur manufacturier tunisien: Un modèle. Centre d'économie et de finance internationales.

Cline, W. R. (2004). Trade policy and Global Poverty. Washington Centre for Global Development, Institute for international Economics.

Cypher, J. M., \& Dietz, J. L. (1997). The process of economic development. London: Rutledge.

Dehove, M., \& Mathis, J. (1987). Le commerce international. DUNOD, Paris.

Fleming, E., \& Blowes, A. (2003). An assessment of commodity export performance in south pacific countries, 1960 to 1999. University of New England Graduate School of Agricultural and Resource Economics, Working Paper $\mathrm{N}^{0} 2003-3$.

Fugaza, M. (2004). Export performance and its determinants: Supply and demand constraints. Policy issues on international Trade and Commodity Study Series N 26 Group, World Bank, Washington, D.C.

International Vanilla Organization. (2001). Annual Report for 1999/2000.

Jayant, P. (2006). Rethinking policy options for export earnings. South centre.

Kasekende, L., \& Atingi-Ego, M. (1999). Impact of liberalization on key markets in Sub-Saharan Africa: The Case of Uganda. Journal of International Development, 11(3), 411-436. http://dx.doi.org/10.1002/(SICI)1099-1328(199905/06)11:3<411::AID-JID591>3.0.CO;2-1

LMC International. (2000). The world market outlook. Paper presented at regional implementation workshop of the sustainable tree crops programs, Accra, Ghana, Oxford UK. 
McGowan, P. (1975). Predicting political instability in tropical Africa. In M. O’leary, \& W. D. Coplin (Eds.), Quantitative techniques in foreign policy analysis and forecasting.

McGowan, P., \& Johnson, T. (1984). Military Coup d'état and under development: A quantitative historical analysis. Journal of Modern African Studies, 22. http://dx.doi.org/10.1017/S0022278X00056275

Michaely, M. (1977). Export and Growth: An empirical investigation. Journal of Development Economics, March, 1977.

Morrissey, O., \& Mold, A. (2006). Explaining Africa's export performance: Taking a new look. Discussion paper 2006.

Musila, J. W. (2004). The common market for Eastern and Southern Africa and Kenya's export trade. International Journal of Social Economics, 31(1/2).

Musinguzi, P., \& Obwona, M. (1999). The use of econometrics in policy design and implementation. Paper presented to MA.EPM students, Institute of Economic policy Research Centre Kampala.

Redding, S., \& Venable, A. J. (2002). Explaining cross-country export performance: International linkage and Internal Geography. Seminar paper.

Thirlwall, A. P. (2000). Trade, trade liberalization and economic growth: Theory and evidence. Economic

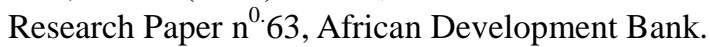

\section{Copyrights}

Copyright for this article is retained by the author(s), with first publication rights granted to the journal.

This is an open-access article distributed under the terms and conditions of the Creative Commons Attribution license (http://creativecommons.org/licenses/by/3.0/). 